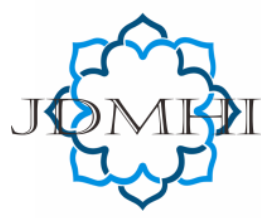

email: jdmhi@walisongo.ac.id

Journal of Digital Marketing and Halal Industry

ISSN: 2716-4810 (print) ISSN: 2716-4802 (online)

\title{
The Role of Akhlak Intelligence: Mediation Between Self -Efficacy and Entrepreneurial Orientation
}

\section{Rahman E1 Junusi}

Universitas Islam Negeri Walisongo Semarang, Indonesia

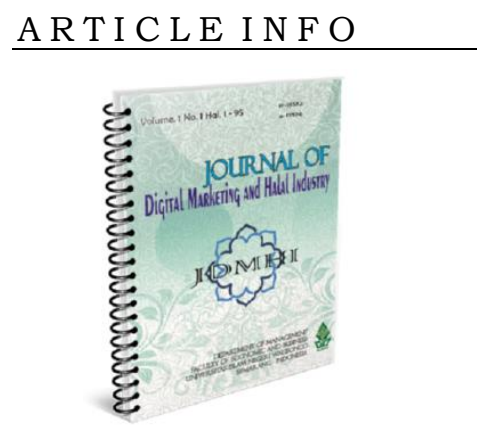

Article history:

Received 28 February 2021

Accepted 26 April 2021

Published 30 April 2021

Keywords:

Self-Efficacy, Entrepreneurial

Orientation, Moral Intelligence,

Muslim Entrepreneur.
A B S T R A C T

This study attempts to fill the gap in the literature between selfefficacy and entrepreneurial orientation (EO). The purpose of this study was to determine the effect of self-efficacy and EO mediated by moral intelligence. Data collection was carried out from a population of 17,603 Muslim entrepreneurs in the city of Semarang who are engaged in the Micro, Small, and Medium Enterprises (MSMEs) sector. The data collected from the online survey was applied to structural equation modeling (SEM). From this study, it was found that self-efficacy has a significant effect on $\mathrm{EO}$ and moral intelligence, while moral intelligence affects EO. This study contributes to the literature on the role of self-efficacy and moral intelligence in increasing EO. The originality of this study is to offer the concept of moral intelligence which plays a central role in the relationship between self-efficacy and EO. Thus, no studies have investigated this causality.

@2021 Journal of Digital Marketing and Halal Industry

\section{Introduction}

Entrepreneurship is a motor of economic growth and social change (Schumpeter, 1934). One of the most widely used constructs to assess entrepreneurial success is EO (Rezaei \& Ortt, 2018), where entrepreneurs have innovative, proactive, and risk-taking behavior. Especially when facing new normality in the
Covid-19 pandemic, entrepreneurs must be able to innovate to create new opportunities to achieve business success. Based on data from the Ministry of Cooperatives and Small and Medium Enterprises (Kemenkop UKM), it shows that in 2018 there were 64,194,057 MSMEs in Indonesia (or around 99 percent of the total business units) and employed $116,978,631$ workers (or about 97 percent of the total workforce in the economic sector)

\footnotetext{
*Corresponding author.email: rahman_eljunusi@walisongo.ac.id DOI: http://dx.doi.org/10.21580/jdmhi.2021.3.1.7744
} 
Small and Medium Enterprises (SMEs) in Central Java are starting to grow.

Data from the Central Java SME Cooperative Office states that SMEs will grow 15 percent in 2020. It is recorded that there are 4 million MSMEs in Central Java, of which 3.7 million are MSMEs in the micro sector, the increase in the number of businesses shows an increase in EO behavior. EO is the basis for making organizational strategy, managerial philosophy, and entrepreneurial behavior. $\mathrm{EO}$ is a multidimensional construct that underlies strategic management and company implementation that characterizes entrepreneurial behavior. Miller, (1983) stated that $\mathrm{EO}$ is an entrepreneur who uses a product innovation approach in the market, dares to take risks, and is the first to innovate proactively, and is ready to compete. Therefore $\mathrm{EO}$ is one of the determining factors for entrepreneurial success.

In literature, EO is an entrepreneurial process that is triggered by self-efficacy (Shane \& Nicolaou, 2015; Fillis \& Rentschler, 2010). Self-efficacy is defined as an entrepreneur's belief about his ability to achieve predetermined performance (Prabhu et al., 2008). Based on the results of the Eniola \& Dada study, (2020); Ladd et al., (2019); Khedhaouria et al., (2015) concluded that selfefficacy did not affect EO. Whereas in other studies Poon et al., (2006); Alvarez et al., (2006); Jiang et al., (2017); Mohd et al., (2014) self-efficacy affects EO. This study attempts to fill the previous research gap between selfefficacy and EO, we offer the concept of moral intelligence which is expected to affect EO performance.
The Islamic view of entrepreneurship, where business is not only seen as a profitable worldly activity but is more oriented towards the pleasure and grace of Allah SWT (Davis, 2013; Junusi \& Mubarok, 2020). Likewise, the Islamic conception of success is very clear, every Muslim is required to compete in goodness (Surat al-Baqarah: 148). This verse can be understood from various points of view, with an entrepreneurial approach, competing in this term can be interpreted as achieving business success with the blessing of Allah SWT (Davis, 2013). This means that entrepreneurship is a way of self-actualization of humans in maintaining life in the world as well as part of the manifestation of devotion to Allah SWT to seek safety in the world and the hereafter. Therefore, intelligence morality plays a role in improving $\mathrm{OE}$ from an Islamic perspective. Therefore, the study aims to determine the effect of self-efficacy and EO mediated by moral intelligence.

\section{Literature Review}

\section{Self Efficacy}

Self-efficacy is related to the belief that a person is capable, through motivation, intelligence, experience, and action, to successfully face life's challenges (Black et al., 2019). Whereas entrepreneurial self-efficacy, defined as an individual's belief in his or her ability to successfully perform roles and tasks, is positively related to entrepreneurial intentions (Chen et al., (1998). Self-efficacy is a motivational construct that has been shown to influence individual activity choices. level of goal, persistence, and performance in various contexts (Zhao et al., 2005). Self-efficacy refers to the personal ability that individuals perceive 
so that they can achieve a specific set of tasks or jobs, and produce effects through cognitive, motivational, and affective processes (Bandura, 1997). According to social cognitive theory, the difference between knowing what to do and acting is because knowledge is controlled by self-referential thought processes (Bandura, 1982). The most influential of thoughts refer to self-efficacy, where individuals assess their self-efficacy and this assessment then influences the actions of people who choose to be involved, in the efforts they will do, and their resilience when faced with obstacles (Bandura 1982).

Self-efficacy is a motivational construct that has been shown to influence individual activity choices, level of goals, persistence, and performance in a variety of contexts. An important component of socio-cognitive theory concerns the malleability of self-efficacy assessments and the process by which these assessments are formed. According to sociocognitive theory, a person's sense of selfefficacy can be influenced through four processes: (a) active mastery, (b) role modeling and representative experience, (c) social persuasion, and (d) self-assessment of physiological states, such as arousal and anxiety (Bandura \& Cervone, 1986).

People who have high levels of self-efficacy tend to believe in their ability to succeed in challenging tasks, as they experience themselves, and by observing others, to achieve significant goals (Black et al., 2019). However, Baron et al., (2016) argued that entrepreneurs tend to have high levels of selfefficacy and optimism which can lead them to set goals that are too high so that they cannot be achieved. Entrepreneurs who fail to achieve goals that cannot even be achieved tend to become disappointed and lose motivation, resulting in decreased performance.

EO refers to the intentions, decisions, actions, and processes of an entrepreneur which functions in the dynamic generation process of creating new businesses or creating new values. Companies with EO are willing to innovate, are relatively proactive about marketplace opportunities, become aggressive towards competitors and take risks (Lumpkin \& Dess, 2001). The study of McGee \& Peterson, (2019) shows that self-efficacy is positively correlated with EO. Meanwhile, Hsiao et al., (2011) stated that self-efficacy has a positive influence on innovative work behavior, meaning that the higher the self-efficacy that entrepreneurs have, the higher the innovative behavior and the higher EO. Therefore we hypothesize as follows: H1: Self-efficacy affects EO Bandura, (1997) defines that "self-efficacy is an assessment of a person against his ability to devise the required action in completing specific tasks at hand. " Self-efficacy in Islam is highly recommended, in the Word of Allah says which means: "Indeed, the Prophet (s) is a good role model for you (namely) for those who hope for (mercy) Allah and (the coming) of the Day of Judgment and He mentions a lot. God." (Surah Al-Ahzab: 21).

The purpose of this verse is to hope for mercy (goodness) in the future or roja' including praiseworthy morals, which are morals that can be useful for strengthening faith and piety in Allah SWT. Self-efficacy is also contained in the word of Allah SWT which means "O people, in fact you have worked earnestly towards your Rabb, so surely you will meet Him". (Surah Al-Insyiqaq: 6). This verse gives us an explanation of Allah's promise to those who are sincere and will surely meet Allah. 
This means that with sincere intentions and hard work, a person will be able to fulfill what he wants. Self-efficacy needs to be developed because it is an important factor that can make the difference between a person's success and failure. In the QS letter. Ar-Ra'du: 11, Allah SWT is hinting to us that if we want to be successful or better at anything then we have to eliminate everything that is the cause of our success and we need high self-efficacy. Success itself must be based on moral values. Therefore we hypothesize as follows:

H2: Self-efficacy affects Moral Intelligence

\section{Moral Intelligence}

Morals are identified with morals and ethics (Habsy, 2005). In terms of morals, it is different from morals, because morals are more indicative of one's inner situation. According to Donagan, (1983) moral is a set of rules of behavior that can be ensured by human reason and bind rational beings. Meanwhile, Luco, (2014) states that moral is a system of rules, psychological states, and a mode of character development that performs the function of enabling mutually beneficial social cooperation. Schaik et al., (2014) argue that morals are doing "right," and what is right is largely determined by the social norms of the societies in which they live.

Meanwhile, Akhlak is the plural form of khulq, which etymologically means habit, behavior, nature, and temperament (Ma'luf, 2002). From Muhammad bin Ajlan from al-Qa'qa bin Hakim from Abu Salih from Abu Hurairah said: "Said Rasulallah SAW:" Verily I was sent to the face of this earth to advance human morals. " Akhlak according to Ibnu Maskawaih is "a mental attitude that encourages someone to take action without requiring thought and consideration." (Rasyad, 2015). Al-Ghazali defines morals with traits embedded in the human soul that gives birth to actions easily without the need for thought or consideration (Al Ghazali, 2004). Al-Ghazali argued that "morality is not just an act, it is not just the ability to act, nor is it knowledge."

Moral Intelligence is a "center of intelligence" for all humans because Moral Intelligence directs other forms of intelligence (cognitive, emotional, and spiritual) to do something valuable. Akhlak Intelligence Akhlak Intelligence is an individual's moral ability that involves spiritual, emotional, and intellectual factors to think, behave, and act based on the values of the Alquran and Hadith which are applied consistently in the goals and actions of life. Moral Intelligence is a type of intelligence that is difficult for competitors to imitate. So Al-Baqir, (2014) concluded that "the essence (character) or morals is a condition or trait that has permeated the soul and became a personality so that various actions arise spontaneously and without making up or requiring thought. If this condition arises good and praiseworthy behavior, and according to the viewpoint of the law and reason, it is called budi pekerti noble (akhlakul karimah) and vice versa, it is called disgraceful character. Whereas in this study, Moral intelligence is defined as the ability of the soul to understand and perform/practice good deeds (noble) following Islamic guidance consistently".

According to al-Ghazali, there are three important moral dimensions of competence for personal and organizational success, namely "(1) the self dimension, namely the person with himself and God, (2) the social 
dimension, namely society, government and relationships with others, and (3) ) the metaphysical dimension, namely faith, and basic guidelines "(Suryadarma \& Haq, 2015). The moral dimension in al-Ghazali's philosophy is based on the concept of Islamic teachings. Meanwhile (Lennick \& Keil, 2005) argues that four dimensions of universal moral capacity include: (1) Integrity, Responsibility, (3) Compassion, and (4) Forgiveness. Meanwhile, the dimensions of morality in various aspects of philosophy can be seen in the perspective of the thoughts of Muslim philosophers, including According to al-Farabi, morals, both praiseworthy and despicable can be obtained through mumarasah (habituation). Praiseworthy morals can be obtained through customs, namely by doing an activity repeatedly for a long time and in a close period. Al-Farabi divides good morals in three ways: First, being brave is a commendable trait, and this quality lies between the two despicable natures, namely blindness (tahawwur) and cowardice (juban). Second, kindness (karam), lies between two despicable qualities, namely: stingy and extravagant (tabriz). Third, maintaining selfrespect ('iffh), and this also lies between two despicable qualities, namely: reliability (khala'ah) and no sense of enjoyment (Rasyad, 2015).

Ployhart et al., (2011) argue that the study of human resources explains how individual differences in knowledge, skills, abilities, and other characteristics contribute to the unit and organizational performance. While morals according to Ibn Ibn Miskawaih are traits or individual characters that are embedded in the soul (Rasyad, 2015). Morals according to Ibn Miskawaih, morals can change with good habits, training, and education. Islam teaches noble moral values so that they become good and happy by training themselves to live them (Rasyad, 2015). The difference in individual personality in Islam is a moral dimension that has never been discussed in Western personality theory. Individual personality affects the way people think, feel, and behave (Costa \& McCrae, 1992). Meanwhile, entrepreneurial behavior is a series of activities that involve creativity and innovation to solve problems and seize market opportunities. Personality represents a potentially important foundation of human resources (Ployhart, 2012). In the Islamic concept, human resources (humans) are the caliphs or as representatives of Allah SWT on earth. With his position as the caliph of Allah SWT. On earth, humans will be held accountable for the sacred duties of their caliphate. In carrying out their duties and responsibilities, humans are equipped with various potentials such as morals, knowledge, skills, minds that give humans the ability to carry out their caliphate duties. Therefore, as Muslim entrepreneurs, entrepreneurs are required to be accountable to Allah SWT as the Cahill and responsible for the success of their business.

\section{Entrepreneurial Orientation}

Entrepreneurial orientation is defined as a company's strategic attitude to engage in innovative, risk-taking, and proactive behavior (Hoskisson et al., 2011). Innovative is a tendency to engage in creativity and experimentation through the introduction of new products or services and to engage in technological leadership through new research and development (R\&D). Meanwhile, risktaking is the tendency to take courage for the act of venturing into unknown markets and undertaking substantial resources for business 
in an uncertain environment. Proactivity is an opportunity-seeking, foresight, characterized by the introduction of new products and services and acting to anticipate future demands (Covin \& Slevin, 1989; Lumpkin \& Dess, 1996, and Miller, 1983). EO reflects the extent to which a business places priority on identifying and exploiting market opportunities in developing corporate strategy (Lumpkin \& Dess, 1996). Hunt \& Morgan, (1997) explains that resource-based view theory (RBV) positions EO as a resource that allows an organization to perform better than its competitors and gain a competitive advantage (Barney, 1991). Lumpkin \& Dess, (1996) suggested that EO leads to a superior organizational performance by facilitating the organization's capacity to recognize innovative opportunities that offer higher profit potential, target premium market segments, and earn a profit. Various organizations consider entrepreneurial behavior important for survival in an increasingly experienced world of accelerating change (Lumpkin \& Dess, 1996).

$\mathrm{EO}$ as a company-level phenomenon has practical implications because it has been found to affect organizational performance thus making it important for organizational success (Narayanan, 2017). EO is a construct at the company level that is closely related to strategic management and strategic decisionmaking processes. EO enables companies to influence market and market behavior by offering innovative products (Boso et al., 2012). Li et al., (2008) observed that the importance of organizational performance, EO is a central measure of how organizations can strategize and take advantage of market opportunities. Lisboa et al., (2011) reminded that companies using RBV can use $\mathrm{EO}$ as a resource with only potential value and which shows the importance of EO. Therefore, companies need to adopt appropriate strategic behaviors, such as adopting a learning orientation to take advantage of the advantages of EO (Lisboa et al., 2011).

\section{Islamic Entrepreneurial Orientation}

The Islamic EO concept is a new concept, where OE activities are based on Islamic rules. As a religion, Islam which places great emphasis on doctrinal principles, Islam views entrepreneurship as a possible activity as long as it remains within the Sharia corridor of the Islamic way of life (Roza et al., 2020). Successful entrepreneurs from the Islamic side are not only measured in terms of material success but other aspects that need to be considered a religion, intelligence, life, honor (Yaacob \& Azmi, 2012). To overcome global challenges as well as identify business opportunities from an unstable environment, thereby making how business is successful. So Muslim entrepreneurs must think strategically, be innovative, be proactive, and be prepared for the risks that may occur. Innovation is related to change and improvement activities. Referring to the main source of Islamic teachings it says "We will not be able to change the condition of a people unless they change themselves" (Surah Ar-Ra'd: 11).

In another verse, Allah SWT says: "a person will not get anything except what is obtained," (Surah An-Najm: 59). These verses are a clear indicator that change is a necessity, and the desire to change is determined by the society itself. In an innovative context, this means that entrepreneurs who are Muslim are important to have a changing nature 
(Amruloh, 2016). Likewise, the risk exists because of uncertainty, and an entrepreneur is a person who is ready to face the risk of success and failure (Zimmerer \& Scarborough, 2010). For this reason, an entrepreneur is required to calculate the opportunities and potential risks that will be faced must be well prepared. Muslim entrepreneurs who are riskminded, in Islam everyone must put their trust and rely on the power of Allah SWT as a result of every deed and business achievement, this self-conception is called tawakkal (Amruloh, 2016). Islam encourages its people to work hard and be diligent. The Quran explains "[....] when you want to make a decision, believe in God for certainty, God loves those who believe in Him (Allah)" (Surah Ali 'Imran: 159).

Islam has broad behavioral guidance to its people, including encouraging every Muslim to be proactive in doing good and changing his destiny. Proactivity is an attitude manifested by those who can take the initiative to always do their best based on honesty. In the word of Allah SWT which means: "it is natural for everyone to take the initiative to achieve something, that every initiative must be based on the values of honesty" (QS Al Baqarah; 149). A Muslim entrepreneur must have an unyielding spirit, be mental, have stamina, and be inspired to take the initiative to elevate individuals and communities (Hoque et al., 2014). Islam advises its people to always try and work hard because with that work, Allah SWT's blessing will be accomplished, "When your prayer is finished, spread it throughout the earth; and seek the grace of Allah SWT and remember Allah a lot so that you will prosper "(Al-Qur'an, 62: 10), humans must have the initiative to seek Allah's blessings and mercy, and those who deliberately seek blessings and Mercy By trying their hardest is a proactive person that attitudes and traits must exist in a Muslim entrepreneur (Amruloh, 2016). So it can be concluded that EO is an inseparable part of Islam, Muslim entrepreneurs have responsibility for the welfare and view business as part of worship.

In Islamic business, it is based on morals that are always held by every Muslim entrepreneur, namely the belief that property belongs to Allah and humans are only tasked with managing it. The person in charge of managing must follow the rules set by the owner and must not break them, in this case, the owner is Allah (Wazin, 2013) as stated in QS An-Najm: 31 "And only belongs to Allah what is there. in heaven and what is in the earth so that He will reward those who do evil for what they have done and reward those who do good with a better reward (heaven)." Islam does not explain entrepreneurship comprehensively, but Islam teaches a moral foundation for its adherents who will carry out entrepreneurial activities (Huda, 2017). Therefore, the hypothesis proposed is as follows:

\section{$\mathrm{H} 3$ : Intelligence morality affects EO}

\section{The Method, data, and analysis}

The object of this research is Muslim entrepreneurs in the city of Semarang who are engaged in the MSMEs sector. There are 17,603 MSMEs, consisting of 1097 small businesses, 21 medium enterprises, and 16385 micro-enterprises. This study involved 200 MSME entrepreneurs as the minimum sample needed to reduce bias in all types of SEM estimates (Loehlin, 2004) using the proportional random sampling technique. 
Questionnaires were distributed online from November to December 2019. Initially, we were looking for email addresses, web or contact person MSMEs which is registered at the MSMEs Office of Semarang City. After being classified, we sent a letter requesting the willingness to fill out the questionnaire, and the questionnaire was sent online. Of the 200 questionnaires distributed, 165 MSMEs had responded, but 6 questionnaires were incomplete so that 159 questionnaires or 79.5 percent of the sample could be further analyzed. Most of the respondents (40\%) were $40-49$ years old. The majority of respondents (66\%) owned their MSMEs, and the length of time for most of them (34\%) was 5- 10 years. Based on education, most of the respondents (47\%) were undergraduate. In addition, 45\% of them have worked for more than 15 years, with a work period of 5-10 years only MSMEs employ less than 5 people. The characteristics of the respondents are described in Table I.

Table I. Description of Respondents

\begin{tabular}{|c|c|c|c|c|c|}
\hline Sex & $\mathrm{n}$ & $\%$ & Ownership & $\mathrm{n}$ & $\%$ \\
\hline Man & 92 & $58 \%$ & One's own & 138 & $66 \%$ \\
\hline $\begin{array}{l}\text { Woman } \\
\text { Age }\end{array}$ & 67 & $42 \%$ & $\begin{array}{l}\text { Cooperation } \\
\text { Education }\end{array}$ & 21 & $34 \%$ \\
\hline$<30$ years old & 11 & $7 \%$ & $\begin{array}{c}\text { Senior high school } \\
\text { equivalent }\end{array}$ & 56 & $35 \%$ \\
\hline $\begin{array}{l}30-39 \text { years old } \\
40-49 \text { years old } \\
\text { - 49 years old }\end{array}$ & $\begin{array}{l}35 \\
63 \\
50\end{array}$ & $\begin{array}{l}22 \% \\
40 \% \\
31 \%\end{array}$ & $\begin{array}{l}\text { Bachelor } \\
\text { Postgraduate } \\
\text { Others }\end{array}$ & $\begin{array}{c}74 \\
7 \\
22\end{array}$ & $\begin{array}{c}47 \% \\
4 \% \\
14 \%\end{array}$ \\
\hline Length of Business & & & $\begin{array}{l}\text { Number of } \\
\text { employees }\end{array}$ & & \\
\hline$<5$ years & 21 & $13 \%$ & $<5$ & 72 & $45 \%$ \\
\hline $5-10$ years & 54 & $34 \%$ & 5. 10 people & 61 & $38 \%$ \\
\hline $11-15$ years & 51 & $32 \%$ & $11-15$ people & 21 & $13 \%$ \\
\hline$>15$ years & 33 & $21 \%$ & > 15 people & 5 & $3 \%$ \\
\hline
\end{tabular}

Data collection was carried out using a questionnaire with a Likert scale at 7 points ranging from 1 strongly disagree to 7 strongly agree. Self-efficacy is measured using the general self-efficacy scale Zhao et al., (2005) and Schwarzer et al., (1997). Example question items: "I can always manage to solve difficult problems if I try hard enough" with Cronbach $\alpha=0.78$. Intelligence morality is measured from Prihatini et al., (2013) which we modified according to entrepreneurial characteristics. The Moral Measurement
Model which is arranged based on the morality construct of students is fit (fit) with the theorized model $(\chi 2=254.93 ;(\mathrm{p})=$ 0.06988 and RMSEA $=0.048$ ). Example of the question item "I am grateful for the way of life that I experience." To measure EO, we used Covin \& Slevin, (1989) and Khedhaouria et al., (2015) three sub-dimensions covering entrepreneurial behavior related to innovation, risk-taking, and proactivity. The extracted mean-variance (AVE) of the OE construct exceeds the recommended threshold 
of 0.50 (i.e., 0.633), all measurement scales have sufficient convergent validity (Hair et al., 2014). An example of a question item is "Owing to the nature of the environment, I favor bold and wide-ranging acts to achieve the company's objectives." We also add a dimension of worship because the object of research is Muslim entrepreneurs, who have an Islamic $\mathrm{OE}$ valuation who want to achieve prosperity in the world and the hereafter. An example of a question item "I play an active role in socio-religious activities to build a friendship."

Descriptive statistical analysis was used to determine the characteristics of the respondents, while confirmatory factor analysis (CFA) was used to test the validity of the measurement model construction. Hypothesis testing and model validity use structural equation modeling (SEM) with AMOS. SEM can estimate a series of relationships between latent constructs simultaneously in a model. The maximum likelihood estimation method was used and the input for the analysis was the item covariance matrix. Chi-square statistics, root mean square error of approximation (RMSEA), comparative fit index (CFI), TuckerLewis index (TLI), normed fit index (NFI), good fit index (GFI), and mean goodness-of-fit index (AGFI) is used to assess the goodness of fit of the model. Hu and Bentler (1999) stated that scores of 0.95 for CFI, TLI, and NFI, and above 0.90 for GFI and AGFI are considered to indicate a good match. For the RMSEA, a score less than 0.05 indicates a good fit, while a score between 0.05 and 0.08 indicates an acceptable fit.

\section{Result and Discussion}

\section{Measurement Model}

Table II provides the mean, standard deviation, and correlation between the study variables. Significant correlations were found between the predictor variables and outcomes. This provides initial support for the research hypothesis.

Tabel II. Mean, Standar deviasi, dan Korelasi

\begin{tabular}{cccccc}
\hline & Mean & SD & 1 & 2 & 3 \\
\hline 1. Self effacacy & 6,1627 & 0,8653 & & & \\
2. Akhlak intelligence & 6,2289 & 0,6564 & $.326^{* *}$ & & \\
3. Entrepreneurial orientation & 6,2727 & 0,8898 & $.564^{* *}$ & $0,503^{* *}$ & \\
\hline
\end{tabular}

Note: ${ }^{* *} \mathrm{p}<0.01 \quad \mathrm{SD}=$ Standard Deviation

Table III. Confirmatory Factor Analysis of Validity and Reliability

\begin{tabular}{|c|c|c|c|c|c|}
\hline \multirow[t]{6}{*}{ Variable } & & Indicator & \multirow{3}{*}{$\begin{array}{c}\text { Loading Fac. } \\
0,57612\end{array}$} & \multirow{3}{*}{$\frac{\text { AVE }}{0,754935}$} & \multirow{2}{*}{$\begin{array}{c}\text { CCR } \\
0,922839\end{array}$} \\
\hline & \multicolumn{2}{|r|}{ 1. Self effacacy } & & & \\
\hline & $\mathrm{X} 1$ & $\begin{array}{l}\text { Identifying new business } \\
\text { opportunities }\end{array}$ & & & \\
\hline & $\mathrm{X} 2$ & Creating new products & 0,89908 & & \\
\hline & X3 & Thinking creatively & 0,92249 & & \\
\hline & $\mathrm{X} 4$ & $\begin{array}{c}\text { Commercializing an idea or new } \\
\text { development }\end{array}$ & 0,76563 & & \\
\hline \multicolumn{3}{|c|}{ 2. Akhlak Intelligence } & & 0,71161 & 0,944218 \\
\hline \multicolumn{6}{|c|}{$\frac{\text { http://journal.walisongo.ac.id/index.php/JDMHI/index }}{\text { DOI: http://dx.doi.org/10.21580/jdmhi.2021.3.1.7744 }}$} \\
\hline
\end{tabular}




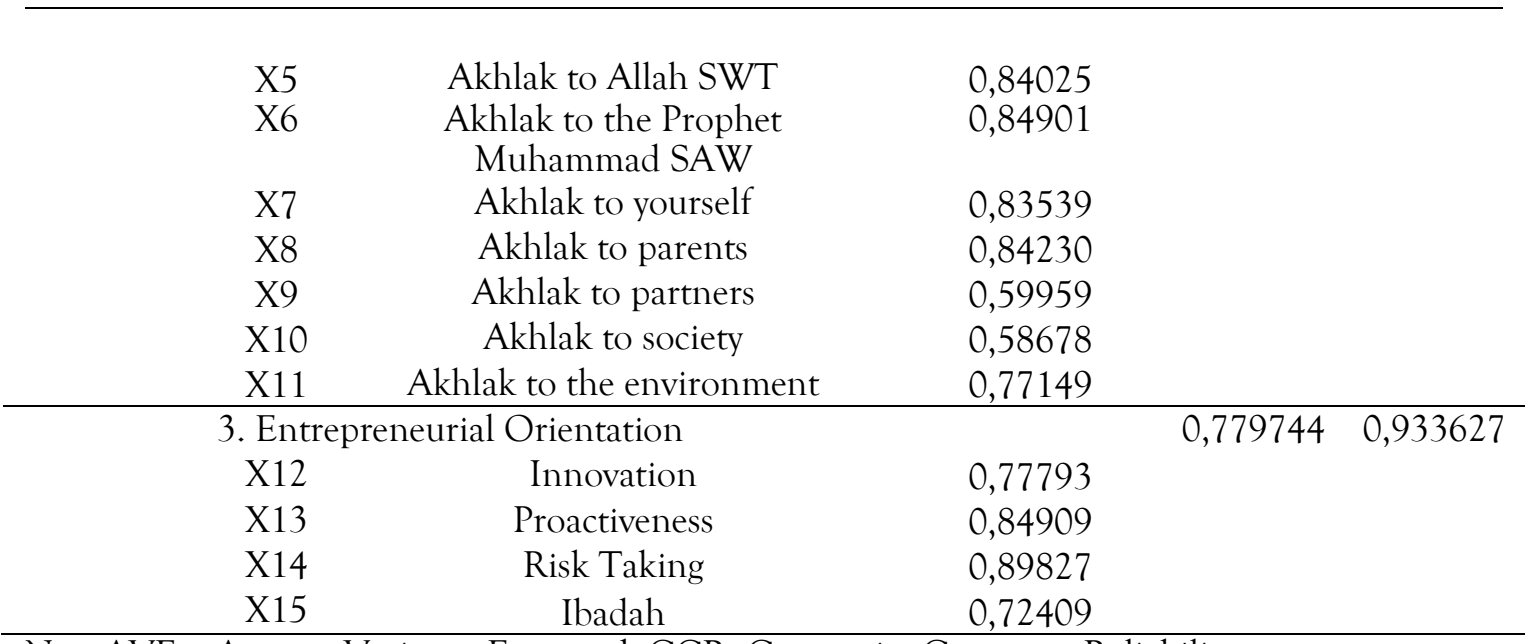

Not: $\mathrm{AVE}=$ Average Variance Extracted, $\mathrm{CCR}=$ Composite Construct Reliability

Table III shows that all variables have a CCR value above 0.7 . The cut-off value of the CCR test is accepted if the value is $>0.70$ (Nunnally, 1978). So it can be concluded that the indicators have good internal consistency. While the AVE value of all variables is above 0.5. The cut-off value of the recommended average variance extracted test is $>0.50$ (Hair et al., 2014). This shows that all variables obtain an AVE value> 0.50 , it can be concluded that the variance extracted from the indicators is greater for the formation of latent variables. Overall, this study has sufficient reliability and validity of data.

\section{Structural Equation Modeling (SEM)}

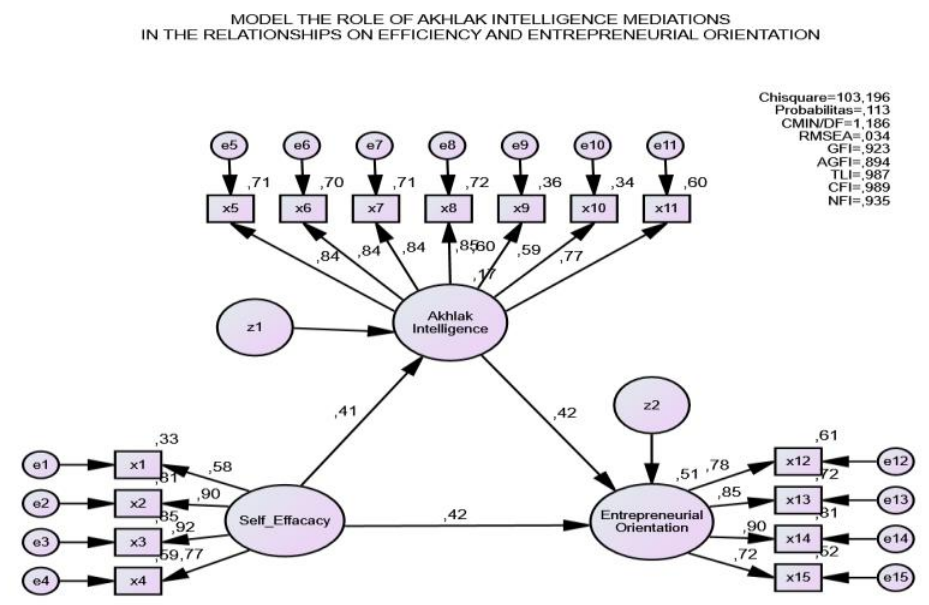

Figure 1 Note:: CMIN / $\mathrm{df}=$ the minimum sample discrepancy function / degree of freedom, RMSEA $=$ Root Mean Square Error of Approximation; NFI = Normed Fit Index; CFI = 
Comparative Fit Index; TLI $=$ Tucker Lewis Index, GFI = Goodness of Fit Index; AGFI = Adjusted

Table IV. SEM Results

\begin{tabular}{cc|ccc}
\hline \multicolumn{2}{c|}{ Alternative hypotheses } & $\begin{array}{c}\text { Direct } \\
\text { effects }\end{array}$ & $\begin{array}{c}\text { Indirect } \\
\text { effects }\end{array}$ & $\begin{array}{c}\text { Total } \\
\text { effects }\end{array}$ \\
\hline H1: Self Effacacy & Entrepreneurial_Orientation &, $423^{* *}$ &, 156 & $0,579^{* *}$ \\
H2: Self Effacacy & Akhlak Intelligence &, $410^{* *}$ & 0 &, $410^{* *}$ \\
H3: Akhlak Intelligence & Entrepreneurial Orientation &, $425^{* *}$ & 0 &, $425^{* *}$ \\
\hline
\end{tabular}
Note :; ${ }^{* *} \mathrm{p}<0.01$

The results of the structural path estimation are shown in Table IV. The model shows that self-efficacy has a significant effect on Entrepreneurial Orientation $(\beta=0.423, \mathrm{t}=$ 5.10477, p <0.01) which supports H1. Selfefficacy has a significant effect on Moral Intelligence with a positive standard path coefficient $(\beta=0.410, t=4.73372, p<0.01)$ which supports $\mathrm{H} 2$. Intelligence morality has a significant effect on Entrepreneurial Orientation $(\beta=0.425, t=5.26540, p<0.01)$ which supports $\mathrm{H} 3$.

\section{Discussion}

Inner model path analysis shows that selfefficacy has a direct and significant effect on EO. The results of this study are in line with the study of McGee \& Peterson, (2019) Poon et al., (2006); Alvarez et al., (2006); Jiang et al., (2017); Mohd et al., (2014) who showed that self-efficacy affects EO. Low self-efficacy can cause individuals to avoid certain situations and this avoidance behavior can make individuals avoid facing fear or build competence. Conversely, high self-efficacy can lead to innovative behavior, high effort, and persistence in facing obstacles (Bandura, 1997). Meanwhile, successful entrepreneurs have; risk-taking, innovation, proactive, competitive aggressiveness, and autonomy.
Entrepreneurs who have high self-efficacy, are ready to take risks, are innovative, aggressive, and proactive in their business, on the other hand, entrepreneurs who have low self-efficacy will tend to avoid risks, are less innovative, reduce aggregation in their business activities. Therefore, the higher the self-efficacy of the entrepreneur, the higher the EO, and conversely the lower the self-efficacy of the entrepreneur, the lower the EO.

Our study found that self-efficacy has a significant direct effect on moral intelligence. Bandura, (1991) said that self-efficacy has a major effect on behavior, while Islam teaches entrepreneurial behavior based on ethics and morals for its adherents. With intelligent morals, entrepreneurs are expected to be able to understand and live up to praiseworthy and despicable morals so that they can lead to a better attitude to life. Good morals arise from the cleanness of heart, purity of spirit, stability of a person, purity of character, and character. Praiseworthy morals can lead to something perfect or lead to the formation of personality. With intelligence morals, moral entrepreneurs can intelligently accept something that should be done, know moral values such as integrity, freedom, responsibility, honesty, justice, forgiveness, and compassion. Entrepreneurs 
with intelligence morals will strengthen their emotional intelligence and lead to entrepreneurs with character.

Our other study findings show that moral intelligence has a significant effect on OE. And the influence of intelligence morals is greater than self-efficacy on EO. This shows that intelligence morality plays a central role in increasing EO. This finding supports this study by Geertz, (1975), in which Geertz presents empirical data that of the seven modern and advanced shops in Modjokuto, six of them are owned by Muslim traders, while of the 24 established factories, 21 of them are owned by Muslim entrepreneurs. pious (akhlakul karimah). Likewise, Sudi Castles, (1967) found persistent Muslim entrepreneurs. These entrepreneurs are generally santri who are frugal and modest in clothing and behavior but have an achievement orientation.

Islamic teaching itself encourages its people to work, work hard, and produce productivity from their own hands, including entrepreneurship. The Prophet Muhammad SAW himself set an example by becoming an entrepreneur. For about 28 years Muhammad SAW has run entrepreneurship. Humans are caliphs on earth who use all the resources around them to fulfill their relatively unlimited desires in the spirit of entrepreneurship. Therefore, entrepreneurs with intellectual morals or entrepreneurs can conduct entrepreneurship based on ethics and morals based on the Koran and hadith, which can increase the success and welfare of the afterlife. Allah SWT has promised that anyone who wants to try will have his fate changed, to be better than the previous situation.

\section{Conclusion}

Based on data analysis and discussion of this study, it can be concluded that self-efficacy has a significant direct effect on intelligence morality. where self-efficacy has a major effect on behavior, while Islam teaches entrepreneurial behavior based on ethics and morals for its adherents. With intelligent morals, entrepreneurs are expected to be able to understand and live up to praiseworthy and despicable morals so that they can lead to a better attitude to life. Good morals arise from the cleanness of heart, purity of spirit, stability of a person, purity of character, and character. Praiseworthy morals can lead to something perfect or lead to the formation of personality. With intelligence morals, moral entrepreneurs can intelligently accept something that should be done, know moral values such as integrity, freedom, responsibility, honesty, justice, forgiveness, and compassion. Entrepreneurs with intelligence morals will strengthen their emotional intelligence and lead to entrepreneurs with character. Our other study findings show that moral intelligence has a significant effect on $\mathrm{OE}$. and the influence of intelligence morals is greater than self-efficacy on EO. This shows that intelligence morality plays a central role in increasing $\mathrm{EO}$.

\section{Recommendations}

This study contributes to the existing literature on self-efficacy, moral intelligence to improve $E O$, especially from an Islamic perspective. The results of this study emphasize that intelligence morality plays a role in efforts to improve OE and contribute to entrepreneurial success. Intelligence morality plays a very important role in mediating the relationship 
between self-efficacy and EO, and moral intelligence can increase EO. Therefore, intelligence morality must be used as a basis for entrepreneurs in carrying out entrepreneurial activities that lead to business success. A limitation of our study, the crosssectional design precludes our ability to form some definitive conclusions about causality. The significant relationships reported in this study may not be causal. In addition to the limited sample size, further studies can be carried out with large sample size and use several institutions or other business sectors to generalize the findings.

\section{References}

Al-Baqir, M. (2014). Mengobati Penyakit Hati Membentuk Akhlak Mulia Diterjemahkan dari Tahdzib Al-Akhlâq wa Mu'ajalat Amradh Al-Qulûb Karya: Al-Imam Abu Hamid Al-Ghazali. Penerbit Mizania.

Al Ghazali, I. (2004). Ringkasan ihya' ulumuddin upaya menghidupkan ilmu agama. Bintang Usaha Jaya.

Alvarez, R. D., DeNoble, A. F., \& Jung, D. (2006). Educational Curricula and SelfEfficacy: Entrepreneurial Orientation and New Venture Intentions among University Students in Mexico. International Research in the Business Disciplines, 5, 379-403. https://doi.org/10.1016/S10747877(06)05019-7

Amruloh, D. A. G. (2016). Entrepreneur Orientation in Islamic Prespective. 2nd International Conference on Bussiness and Social Science, 10.

Bandura, A. (1982). Self-efficacy mechanism in human agency. American Psychologist, $37(2)$, 122-147. https://doi.org/10.1037/0003066X.37.2.122

Bandura, A. (1991). Social cognitive theory of moral thought and action. In Handbook of moral behavior and development (Vol. 1, pp. 45-103). Hillsdale, New Jersey, pp. 45.

Bandura, A. (1997). Self-efficacy: the Exercise of Control. W.H.Freeman and Company, New York.

Bandura, A., \& Cervone, D. (1986). Differential engagement of self-reactive influences in cognitive motivation. Organizational Behavior and Human Decision Processes, 38(1), 92-113. https://doi.org/10.1016/0749. 5978(86)90028-2

Barney, J. B. (1991). Firm Reources ad Sustained Competitive Advantege. In Journal of Management (Vol. 17, Issue 1, pp. 99-120).

Baron, R. A., Mueller, B. A., \& Wolfe, M. T. (2016). Self-efficacy and entrepreneurs' adoption of unattainable goals: The restraining effects of self-control. Journal of Business Venturing, 31(1), 55-71. https://doi.org/10.1016/j.jbusvent.2015 .08 .002

Black, J., Kim, K., Rhee, S., Wang, K., \& Sakchutchawan, S. (2019). Self-efficacy and emotional intelligence: Influencing team cohesion to enhance team performance. Team Performance Management, 25(1-2), 100-119. https://doi.org/10.1108/TPM-01-20180005 
Boso, N., Cadogan, J. W., \& Story, V. M. (2012). Complementary effect of entrepreneurial and market orientations on export new product success under differing levels of competitive intensity and financial capital. International Business Review, 21(4), 667-681. https://doi.org/10.1016/j.ibusrev.2011. 07.009

Castles, L. (1967). Religion, Politics, and Economic Behavior in Java: The Kudus Cigarette Industry. New Haven: Southeast Asia Studies, Yale University. https://doi.org/10.32678/ijei.v4i1.10

Chen, C. C., Greene, P. G., \& Crick, A. (1998). Does entrepreneurial self-efficacy distinguish entrepreneurs from managers? Journal of Business Venturing, 13(4), 295-316.

Costa, P. T., \& McCrae, R. R. (1992). Normal Personality Assessment in Clinical Practice: The NEO Personality Inventory. Psychological Assessment, 4(1), 5-13. https://doi.org/10.1037/10403590.4.1.5

Covin, J. G., \& Slevin, D. P. (1989). Strategic management of small firms in hostile and benign environments. Strategic Management Journal, 10(1), 75-87. https://doi.org/10.1002/smj.425010010 7

Davis, M. K. (2013). Entrepreneurship : an Islamic perspective. International Journal Entrepreneurship and Small Busines, 20(1), 63-69.

Donagan, A. (1983). The Theory of Morality. Noûs, $17(2)$, 303-308.
https://doi.org/10.1017/CBO97811074 15324.004

Eniola, A. A., \& Dada, D. A. (2020). Entrepreneurial self-efficacy, institutional environment, and entrepreneurial orientation for SME: A review. International Journal of Research Studies in Management, $\quad 8(2), \quad 10-22$. https://doi.org/10.5861/ijrsm.2020.401 7

FILLIS, I., \& RENTSCHLER, R. (2010). the Role of Creativity in Entrepreneurship. Journal of Enterprising Culture, 18(01), 4981.

https://doi.org/10.1142/s02184958100 00501

Geertz, C. (1975). GeEthos, World View, and the Analysis of Sacred Symbolis" dalam Interpretation of Culture. New York: Basic Book, Inc. https://doi.org/10.32678/ijei.v4i1.10

Habsy, H. Al. (2005). Kamus Al-Kautsar: Terjemahan lengkap Bahasa Arab- Bahasa Malaysia. Victory Agencie.

Hair, J. F. J., Black, W. C., Babin, B. J., \& Anderson, R. . (2014). Multivariate Data Analysis (MVDA). In Multivariate Data Analysis (7 th). Pearson Education Limited. https://doi.org/10.1002/978111889523 8.ch8

Hoque, N., Mamun, A., \& Mohammad Ahshanul Mamun, A. (2014). Dynamics and traits of entrepreneurship: an Islamic approach. World Journal of Entrepreneurship, Management and Sustainable Development, 10(2), 128-142. 
https://doi.org/10.1108/wjemsd-042013-0027

Hoskisson, R. E., Covin, J., Volberda, H. W., \& Johnson, R. A. (2011). Revitalizing Entrepreneurship: The Search for New Research Opportunities. Journal of Management Studies, 48(6), 1141-1168. https://doi.org/10.1111/j.1467. 6486.2010.00997.x

Hsiao, H.-C., Chang, J.-C., Tu, Y.-L., \& Chen, S.-C. (2011). The Influence of Teachers' Self-efficacy on Innovative Work Behavior. International Conference on Social Science and Humanity, 5(1), 233237.

Hu, L.-T., \& Bentler, P. . (1999). Cutoff criteria for fit indexes in covariance structure analysis: conventional criteria versus new alternatives. Structural Equation Modeling, 6(1), 1-55.

Huda, C. (2017). Etos Kerja Pengusaha Muslim (Studi Kasus pada Pengusaha Muslim Alumni UIN Walisongo Semarang). Economica: Jurnal Ekonomi Islam, $7(2)$, 79. https://doi.org/10.21580/economica.20 16.7.2.1156

Hunt, S. D., \& Morgan, R. M. (1997). Resource-advantage theory: A snake swallowing its tail or a general theory of competition? Journal of Marketing, 61(4), $74-82$.

https://doi.org/10.2307/1252088

Jiang, H., Xiong, W., \& Cao, Y. (2017). Research on the mechanism of entrepreneurial education quality, entrepreneurial self-efficacy and entrepreneurial intention in social sciences, engineering and science education. Eurasia Journal of Mathematics, Science and Technology Education, 13(7), 3709-3721. https://doi.org/10.12973/eurasia.2017. 00754a

Junusi, R. El, \& Mubarok, F. K. (2020). Islamic Entrepreneur Resilience Model: Retail Business Survives During Crisis. Journal of Digital Marketing and Halal Industry, 2(2), 89. https://doi.org/10.21580/jdmhi.2020.2. 2.6350

Khedhaouria, A., Gurău, C., \& Torrès, O. (2015). Creativity, self-efficacy, and smallfirm performance: the mediating role of entrepreneurial orientation. In Small Business Economics (Vol. 44, Issue 3, pp. 485-504).

https://doi.org/10.1007/s11187-0149608-y

Ladd, T., Hind, P., \& Lawrence, J. (2019). Entrepreneurial orientation, Waynesian self-efficacy for searching and marshaling, and intention across gender and region of origin. Journal of Small Business and Entrepreneurship, 31(5), 391-411. https://doi.org/10.1080/08276331.201 8.1459016

Lennick, D., \& Keil, F. (2005). Moral Intelligence: Enhancing Business Performance and Leadership Success. Publishing as Prentice Hall.

Li, Y., Zhao, Y., Tan, J., \& Liu, Y. (2008). Orientation on Market Evidence from Chinese Small Firms *. Journal of Small Business Management, 46(1), 113-133.

Lisboa, A., Skarmeas, D., \& Lages, C. (2011). 
Entrepreneurial orientation, exploitative and explorative capabilities, and performance outcomes in export markets: A resource-based approach. Industrial Marketing Management, 40(8), 1274-1284.

https://doi.org/10.1016/j.indmarman.2 011.10 .013

Luco, A. (2014). The Definition of Morality: Threading the Needle. Social Theory and Practice, 40(3), 361-387.

Lumpkin, G. ., \& Dess, G. G. (2001). Linking two dimensions of entrepreneurial orientation to firm performance. Journal of Business Venturing, 16(5), 429-451.

Lumpkin, G. T., \& Dess, G. G. (1996). Clarifying the Entrepreneurial Orientation Construct and Linking it to Performance. Academy of Management Review, 21(1), 135-172.

Ma'luf, L. (2002). Kamus al Munjid fi al Lughah wa al A'lam (30th ed.). Daar Al-Masyriq.

McGee, J. E., \& Peterson, M. (2019). The Long-Term Impact of Entrepreneurial Self-Efficacy and Entrepreneurial Orientation on Venture Performance. Journal of Small Business Management, 57(3), 720-737. https://doi.org/10.1111/jsbm.12324

Miller, D. (1983). The Correlates of Entrepreneurship in Three Types of Firms. Management Science, 29(7), 770791.

https://doi.org/10.1287/mnsc.29.7.770

Mohd, R., Kirana, K., Kamaruddin, B. H., Zainuddin, A., \& Ghazali, M. C. (2014). The Mediatory Effect of Self-efficacy on the Relationship between Religious Values and Entrepreneurial Orientations: A Case of Malay Owner Managers of SMEs in Manufacturing Industry. Procedia - Social and Behavioral Sciences, 130(June 2015), 96-104. https://doi.org/10.1016/j.sbspro.2014.0 4.012

Narayanan, V. (2017). Theorizing on entrepreneurial orientation in international business: A synthetic review. Przedsiębiorczość Międzynarodowa, 3(1), 9-23. https://doi.org/10.15678/pm.2017.030 1.01

Nunnally, J. C. (1978). Psychometric theory. 2nd Edition. McGraw-Hill.

Ployhart, R. E. (2012). From Possible to Probable: The Psychology of Competitive Advantage. Industrial and Organizational Psychology, 5(1), 120-126. https://doi.org/10.1111/j.17549434.2011.01417.x

Ployhart, R. E., Van Iddekinge, C. H., \& Mackenzie, W. I. (2011). Acquiring and developing human capital in service contexts: The interconnectedness of human capital resources. Academy of Management Journal, 54(2), 353-368. https://doi.org/10.5465/AMJ.2011.602 63097

Poon, J. M. L., Ainuddin, R. A., \& Junit, S. H. (2006). Effects of self-concept traits and entrepreneurial orientation on firm performance. International Small Business Journal, 24(1), 61-82. https://doi.org/10.1177/026624260605 9779 
Prabhu, V., Sutton, C., \& Sauser, W. (2008). Creativity and certain personality traits: Understanding the mediating effect of intrinsic motivation. Creativity Research Journal, 20(1), 53-66. https://doi.org/10.1080/104004107018 41955

Prihatini, S., Mardapi, D., \& Sutrisno. (2013). Pengembangan Model Penilaian Akhlak Peserta Didik Madrasah Aliyah. Jurnal Penelitian Dan Evaluasi Pendidikan, 17(2), 347-368.

Rasyad. (2015). Dimensi Akhlak dalam Filsafat Islam. Substantia, 17(1), 89-102.

Rezaei, J., \& Ortt, R. (2018). Entrepreneurial orientation and firm performance: the mediating role of functional performances. In Management Research Review (Vol. 41, Issue 7, pp. 878-900). https://doi.org/10.1108/MRR-03-2017. 0092

Roza, S., Sriayudha, Y., \& Octavia, A. (2020). Entrepreneurial Passion, Entrepreneurial Alertness and Islamic Entrepreneurial Orientation: Its Application To the Muslimah Entrepreneur. Dinasti International Journal of Education Management And Social Science, 2(2), 254265.

https://doi.org/10.31933/dijemss.v2i2.6 54

Schaik, C. van, Burkart, J. M., Jaeggi, A. V., \& Rohr, C. R. von. (2014). Morality as a Biological Adaptation - An Evolutionary Model Based on the Lifestyle of Human Foragers. In M. Christen, C. van Schaik, J. Fischer, M. Huppenbauer, \& C. Tanner (Eds.), Empirically Informed Ethics: Morality between Facts and Norms (pp. 65-
84). Springer International Publishing Switzerland.

https://doi.org/10.4013/fsu.2015.162.0 7

Schumpeter, J. A. (1934). The Theory of Economic Development. Harvard University Press, Cambridge, MA.

Schwarzer, R., Bäßler, J., Kwiatek, P., Schröder, K., \& Zhang, J. X. (1997). The assessment of optimistic self-beliefs: Comparison of the German, Spanish, and Chinese versions of the general selfefficacy scale. Applied Psychology, 46(1), 69-88. https://doi.org/10.1111/j.14640597.1997.tb01096.x

Shane, S., \& Nicolaou, N. (2015). Creative personality, opportunity recognition and the tendency to start businesses: A study of their genetic predispositions. Journal of Business Venturing, 30(3), 407-419. https://doi.org/10.1016/j.jbusvent.2014 .04 .001

Suryadarma, Y., \& Haq, A. H. (2015). Pendidikan Akhlak Menurut Imam AlGhazali. At Ta'Dib, 10(2), 361-381.

Wazin. (2013). Pengkarakteran Wirausaha Muslim. Islamiconomic, 4(1), 1-12.

Yaacob, Y., \& Azmi, I. A. G. (2012). Entrepreneur's Social Responsibilities From Islamic Perspective: A Study of Muslim Entrepreneurs In Malaysia. Procedia - Social and Behavioral Sciences, 58(1999), 1131-1138. https://doi.org/10.1016/j.sbspro.2012.0 9.1094

Zhao, H., Hills, G. E., \& Seibert, S. E. (2005). The mediating role of self-efficacy in the development of entrepreneurial 
Journal of Digital Marketing And Halal Industry

Vol. 3, No. 1 (2021) 1-18

intentions. Journal of Applied Psychology, 90(6), 1265-1272.

https://doi.org/10.1037/0021-

9010.90.6.1265

Zimmerer, T. W., \& Scarborough, N. M. (2010). Essentials of Entrepreneurship and Small Business Management -5/E. Pearson Prentice Hall. 